\title{
The value of haptic feedback in conventional and robot-assisted minimal invasive surgery and virtual reality training: a current review
}

\author{
O. A. J. van der Meijden · M. P. Schijven
}

Received: 23 August 2008/Accepted: 4 December 2008/Published online: 1 January 2009

(C) The Author(s) 2008. This article is published with open access at Springerlink.com

\begin{abstract}
Background Virtual reality (VR) as surgical training tool has become a state-of-the-art technique in training and teaching skills for minimally invasive surgery (MIS). Although intuitively appealing, the true benefits of haptic (VR training) platforms are unknown. Many questions about haptic feedback in the different areas of surgical skills (training) need to be answered before adding costly haptic feedback in VR simulation for MIS training. This study was designed to review the current status and value of haptic feedback in conventional and robot-assisted MIS and training by using virtual reality simulation.

Methods A systematic review of the literature was undertaken using PubMed and MEDLINE. The following search terms were used: Haptic feedback OR Haptics OR Force feedback AND/OR Minimal Invasive Surgery AND/ OR Minimal Access Surgery AND/OR Robotics AND/OR Robotic Surgery AND/OR Endoscopic Surgery AND/OR Virtual Reality AND/OR Simulation OR Surgical Training/ Education.

Results The results were assessed according to level of evidence as reflected by the Oxford Centre of Evidencebased Medicine Levels of Evidence.

Conclusions In the current literature, no firm consensus exists on the importance of haptic feedback in performing minimally invasive surgery. Although the majority of the results show positive assessment of the benefits of force feedback, results are ambivalent and not unanimous on the
\end{abstract}

O. A. J. van der Meijden · M. P. Schijven ( $\square)$

Department of Surgery, University Medical Centre Utrecht, P.O. Box 85500, 3508 GA Utrecht, The Netherlands

e-mail: m.p.schijven@umcutrecht.nl

O. A. J. van der Meijden

e-mail: oliviervandermeijden@ $@$ hotmail.com subject. Benefits are least disputed when related to surgery using robotics, because there is no haptic feedback in currently used robotics. The addition of haptics is believed to reduce surgical errors resulting from a lack of it, especially in knot tying. Little research has been performed in the area of robot-assisted endoscopic surgical training, but results seem promising. Concerning VR training, results indicate that haptic feedback is important during the early phase of psychomotor skill acquisition.

Keywords Haptic feedback - Minimal invasive surgery . Robotic surgery $\cdot$ Surgical training · Virtual reality

In every day life, the importance of the sense of touch is eminent. Recent studies have shown that loss of sense of touch can be catastrophic. Skilled actions, such as using tools, holding objects, or even plain walking, may become almost impossible upon losing the sense of touch [1]. Touch is the earliest sense developed in human embryology and is believed to be essential for good clinical practice [2, 3]. Therefore, the potential of haptic technology may not be underestimated for clinical specialities that rely on sensory input, such as minimally invasive surgery (MIS).

In surgery, haptic or force feedback refers to the sense of touch that a surgeon experiences-both consciously and unconsciously-while performing surgery. It is known that in MIS haptics are deprived compared with open surgery [47]. Haptics provide sensation to numerous surgical procedures, varying from structure to structure and depending on type of force applied, and relates to tissue damage, straightness of suturing, and task completion time [3, 8].

Within the various applications of MIS, a distinction can be made between conventional endoscopic surgery (CES) 
and robot-assisted endoscopic surgery (RAS). For CES the surgeon operates directly on the patient by using an endoscopic interface, whereas for RAS a computer-instrumented interface (surgical robot) is positioned between the surgeon and patient. Deprived haptic feedback, as experienced while performing CES, or a total lack of it, as experienced while performing RAS, may be a missing feature for the endoscopic surgeon [2, 9-11].

Next to ongoing developments in MIS, such as RAS, surgical training in MIS also has experienced rapid change. Virtual reality (VR) simulation is a computer-based application for MIS training. Beyond its infancy, VR simulation is integrated in many MIS training curricula throughout the world [9, 10, 12-16].

A comment that often is heard when discussing the integration of VR systems in MIS training curricula is the omission of haptic feedback in the many "basic" types of MIS-VR trainers. Again, no consensus is available on the importance of missing this type of feedback in training MIS surgery. Before validated implementation of costly haptic devices in basic and advanced MIS training can be accounted for, the importance of the lack of haptics in conventional CES and its omission in RAS should be assessed.

No clear consensus within the MIS performing community exists on the importance of deprived haptic feedback in MIS, related to MIS surgical outcome, and therefore in MIS training. We present a current overview of studies that assessed haptics in MIS and VR simulation and its possible implications. All studies were inventorized according to level of evidence as reflected by the Oxford Centre of Evidence-based Medicine Levels of Evidence [17].

Minimal invasive surgery: comparing conventional endoscopic surgery with robotic-assisted endoscopic surgery: The principle of MIS (e.g., operating through minimal incisions) is the same in CES as it is in RAS; however, there are some differences. The most obvious one is that in RAS a surgical robot is placed between the endoscopic surgical instruments and operating hands of the surgeon. This is referred to as "the master-slave principle." The surgeon performs the movements while seated comfortably in a surgical operating console (master) and the movements are translated to the arms of a MIS robot (slave), thus executing them. The benefits commonly attributed to MIS, such as reduced morbidity, lower infection rates, less pain, faster recovery, and improved cosmesis, apply equally to CES and RAS [18-24].

A potential major drawback, comparing RAS to CES, is the absence of haptic feedback in RAS. In CES force feedback is experienced by the surgeon through the laparoscopic instrument handles, resulting from the interaction of the laparoscopic instruments tips with the tissue. In RAS, the latter end is formed by robotic arms, teleoperized by a console in which the surgeon performs his gestures.
As a result, no force feedback or haptics resulting from interaction with patient's tissue are provided to the surgeon. In the literature, this is considered to be a (potential) major drawback because of the experienced difficulties in applying the correct amount of force on delicate tissue and suture materials, resulting in risk of slippage and tissue damage [4, 7, 25, 26].

Training MIS: Surgical training has become a subject of discussion and ongoing change. Receiving full training "on the job" is challenged by concerns for patient safety and resident working hour restrictions [6]. Therefore, alternative training methods must be provided to the resident within validated training curricula $[6,27]$. These curricula may employ simple box trainers, inanimate and (live) animal models, and VR simulators [6].

Box trainers are well-known, inexpensive, and offer the experience of haptic feedback in contrast to nonhapticenhanced VR simulators. Animate models are logistically and ethically challenging. Virtual reality offers the possibility to train psychomotor skills using software, varying from simulating basic laparoscopic exercises to simple surgical tasks toward full operative procedures. By using repetitive VR training, a substantial part of the individual learning curve can be overcome before practicing on real patients $[2,14,16]$. One of the newest developments in VR training is VR training for RAS [11, 28, 29].

VR simulators offer value benefits in training compared with box trainers, in terms of repetitive training scenarios overcoming psychomotor learning curves, integration of didactic modalities, and objective assessment of outcome parameters.

Haptic feedback in MIS and training: Although nonhaptic VR simulators have proven a transfer of skill to the operative room [9, 12-14, 30], the lack of haptic feedback is still considered as a potential drawback. The general opinion is that, in theory, realistic procedural simulations with haptic feedback lead to better performances, faster performance curves, and a high transfer of operative skill [18]. No consensus in literature, however, could be found about the importance of haptic feedback in VR simulation devices and the right manner of implementation.

To assess the importance of haptics, one-first needs to know precisely what the limitations are in haptic sensations when performing or training MIS. What kind of haptic input - or how many different levels of force-does a MIS surgeon actually receive? And what type of force generated through haptic feedback is optimal? In what manner is the current loss of haptic feedback substituted to perform optimal MIS and VR training and are there alternatives? In which areas of VR training and in which way can haptic feedback be applied? And, most importantly, are results in CES or RAS improving by adding haptic feedback? Is an improvement in MIS outcome by adding haptics a stable 
trait, or does the effect wear off when a surgeon becomes more experienced in performing a certain MIS procedure? These questions are addressed in the following paragraphs.

\section{Haptic feedback in conventional endoscopic surgery}

Present research focusing on haptic feedback and CES assesses aspects such as the decrease of haptic feedback in endoscopic surgery (due to the interposition of endoscopic instruments) and impaired sensoric feelings [4-6, 25, 3133]. It is known that in surgery, sensoric stimuli are best felt through bare hands, followed by conventional surgical instruments, and lastly, by endoscopic instruments [32, 34, 35]. The amount of sensitivity loss measured when using endoscopic instrumentation instead of bare fingers varies between a factor of 8-20 [32]. Theoretically, however, using the instrument as a lever, the force generated from contact with an organ can be fed back to the surgeon 0.24.5 times the force generated by the organ-instrument interaction. This could imply a sensitivity enhancement, or at least a disturbance of haptic sensation, depending on the depth of instrument insertion into the body cavity [26]. Although the amount of force feedback is reduced, the interpretation of texture, shape, and tissue consistency are altered but present upon use of conventional endoscopic instruments [5, 20, 26, 35-38].

An endoscopic surgeon applies forces at the extremity of the instruments ranging from $0.5-12$ Newton. These forces are translated to the instrument tips during endoscopic gestures, resulting into tissue handling ranging from 0.110.5 Newton [26, 38].

The main cause of disturbance of haptic sensations is frictional forces, which may exceed 3 Newton [26]. Frictional forces are forces caused by the friction between the instruments and the trocar. The fluctuation in frictional forces depends on the type of trocar used, the brand of the particular endoscopic instrument used, and the movement direction and velocity of the endoscopic instruments [39].

Frictional force may be reduced when enhancing the mechanical efficiency of the endoscopic instrument, for instance by lubricating the shaft of the instrument [39]. As a result, the amount of haptic feedback may be enhanced $[32,34]$. The optimal mechanical efficiency depends on the specific task being performed [25, 38-43].

It seems that by combining several factors, such as visual feedback, haptic feedback, and endoscopic experience, performances of certain surgical tasks can be improved [5, 25]. Analyses performed by Tholey et al. show that no significant differences in performance occur when only one of these factors was present [5].

"Endoscopic experience" is a key factor in many of the assessed studies. The fact that experienced surgeons are able to perform both CES and RAS successfully is an indication for some researchers that the possible positive effect of the addition of haptic feedback may be overestimated [25, 26]. It is suggested that haptic feedback should not be superimposed, because it may be subject to interfering forces. Furthermore, the amount of force feedback will differ according to, and depend on, the specific task being performed. High variance in interfering forces may worsen an endoscopic surgeon's performance during tasks that require utmost precision [26, 39].

Patient safety is, as always in the field of medical research, an important aspect in the discussion on the importance of haptic feedback in MIS. Several authors assessed this area matter by conducting research in the occurrence of surgical error during CES, performed without force feedback. Video analysis of endoscopic procedures showed tissue slippage occurring during grasping actions, resulting in tissue damage, when haptic feedback was absent $[25,40,44,45]$.

A recent review by Westebring-van der Putten et al. supports the concept of using haptic feedback in MIS. It is stated that the concept is indeed promising, although rare in actual presence. Surgeons could possibly benefit from additional feedback, but there is still much to learn about the specifics and advantages of included force feedback when it comes to preventing surgical errors [46]. The results are summarized in Table 1.

\section{Haptic feedback in robot-assisted endoscopic surgery}

In RAS, lack of force feedback may prologue operative times and learning curves, and increase the risk of surgical errors [38, 47-50]. Bethea et al. reported that even experienced surgeons training with RAS often tear apart sutures and damage delicate tissues [7]. This is attributed to the exertion of excessive force by the surgeon during his performance, because any form of force feedback is absent. In a study investigating the effects of haptic feedback on blunt dissection using a telerobotic system, Wagner et al. found that the absence of haptic feedback increased errors causing tissue damage by a mere factor of 3 [51].

The loss of force feedback in RAS compared with CES may be balanced partly by the restoration of three-dimensional vision. This is important because in the current operative situation, a surgeon must foremost rely on the visual deformation of tissue when performing MIS in general, and even more so in performing RAS [7, 51]. Several studies report direct improvements in performance times, accuracy, and decrease in error rates for both inexperienced and experienced endoscopic surgeons, when using three-dimensional vision instead of conventional two-dimensional vision in MIS [52-54]. 


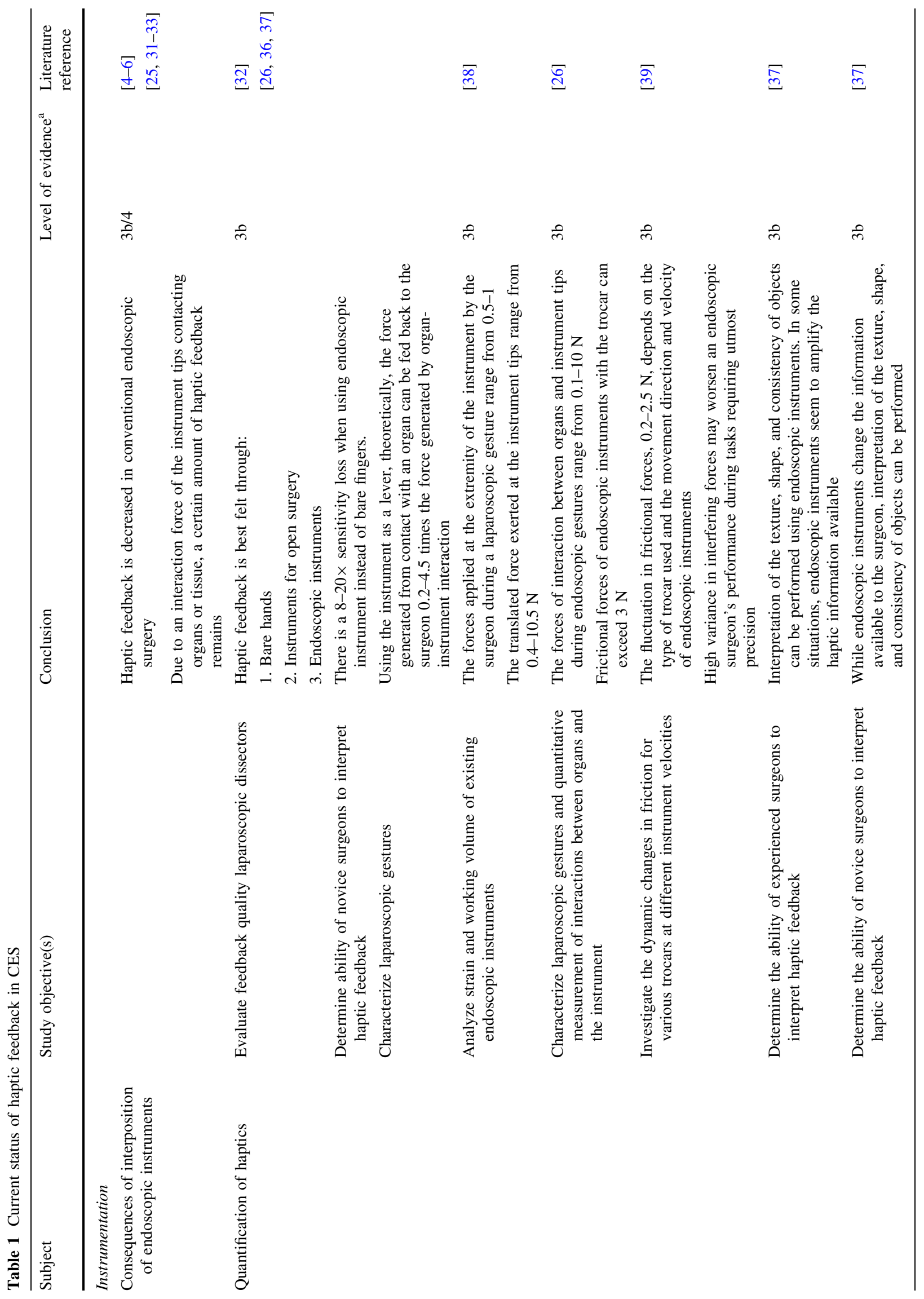




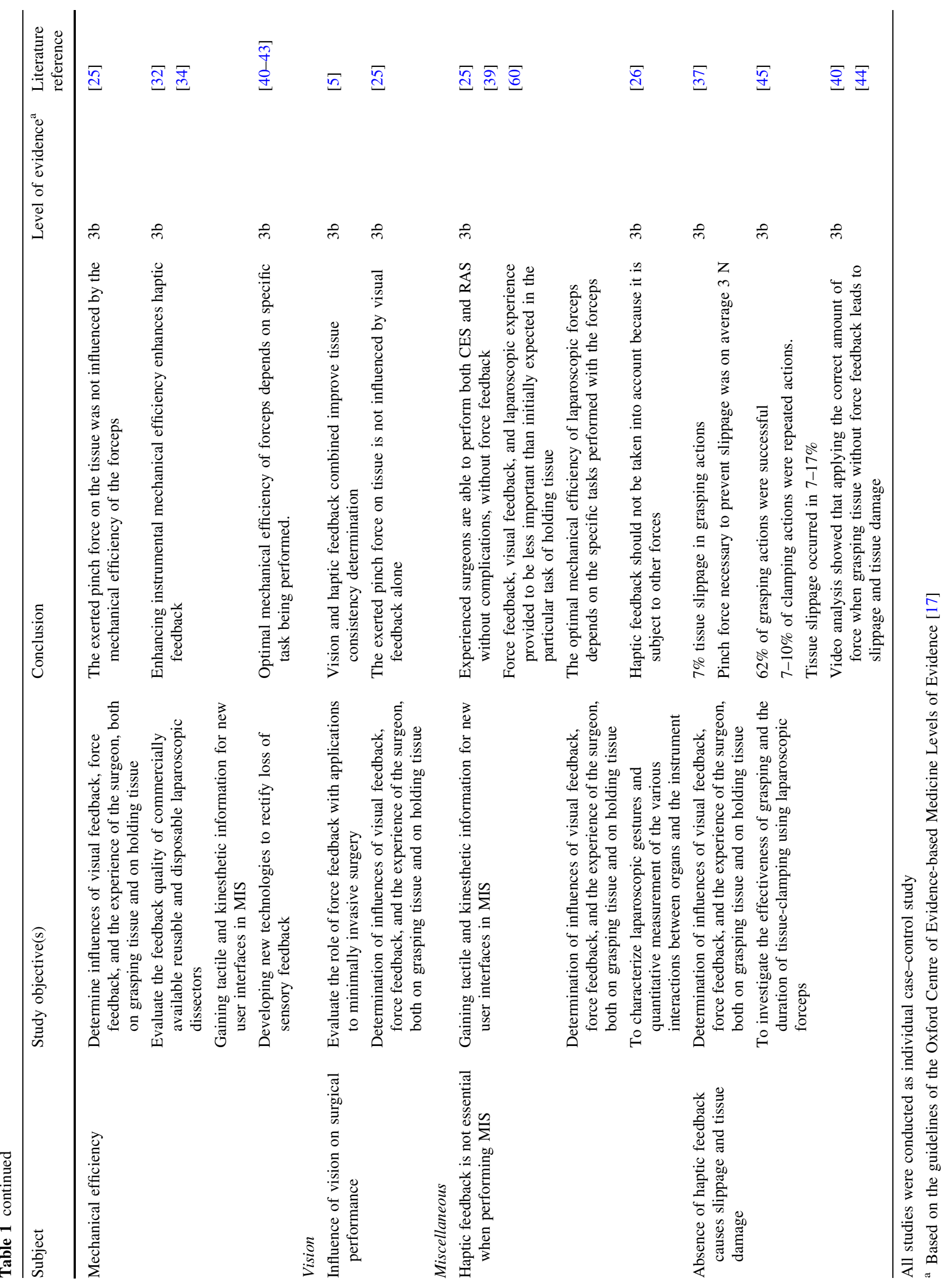


Some study results suggest that other forms of feedback may prove a successful compensation for loss of force feedback, for example, visual cues indicating the visual deformation of tissue. This is a suitable substitution if the surgeon is able to correlate the forces applied and tissue deflection on a good internal model of tissue consistency $[7,51]$. Bethea et al. demonstrated that during robotic knot tying, greater and more consistent tension may be applied to suture materials when haptic feedback is applied [7]. Haptic feedback was supplied in the form of a visual color bar scale, which changed color when different forces were applied. In the literature, this concept often is called "visual haptics."

The use of visual and auditory feedback of force levels combined has been found to improve consistency of applied forces during knot tying, even more consistent than with those being hand-tied. In a preliminary study by Okamura et al., auditory feedback as sensory substitution was tested and proven a success [55]. The accompanying additional noises, added to sounds already present during operation, such as those made by hemodynamic/pulse oximetry monitors, may undesirably interfere with the surgical process $[7,53]$.

Addition of force feedback in MIS would enable surgeons to "feel" tissue characteristics, identify pathologic tissue, and tie sutures with appropriate tension, as in open surgery [54]. In the past, various system technologies, actuators, and forms of sensory substitution have been tested to accomplish an alternative for the missing tactile information, to estimate the amount of force applied [56]. Tavakoli et al. successfully describe a robotic sensory endeffector [57]. Besides the incorporation of haptic feedback, authors suggest the end-effector to be of use in evaluating skills and monitor learning curves in RAS training.

A new development in the area of robotic sensory endeffector technology is pneumatic tactile displays [56]. Preliminary human perceptual tests of King et al. with implemented pneumatic balloon actuators provide effective force feedback to the human index finger [55]. So far, the implementation of force sensors has not been commercially successful, despite the fact that there are currently several robotic surgical systems on the market $[4,58]$. Reasons for this are unclear; (mass) production and research of the above-mentioned sensory end-effector technologies are probably still in an experimental phase. The results are summarized in Table 2.

Most studies conducted regarding CES and the possible influence of haptic feedback are case-control-type surveys and literary reviews. Although the number of studies conducted concerning RAS and haptic feedback is scarce compared with the number of studies concerning CES and force feedback, the level of evidence and results are alike. Study populations are small and do not involve multiple study centers. Therefore, they can be classified as having a level of evidence of 4 or $3 \mathrm{~b}$ at most, according to the guidelines of the Oxford Centre of Evidence-based Medicine Levels of Evidence [17].

\section{Haptic feedback in VR (MIS) training}

\section{Application of haptic feedback in virtual reality training}

According to Fager et al., haptics using VR simulation can be implicated in two distinct areas: medical training and clinical practice [2]. Overviews of MIS-haptic training possibilities, potential VR implications, and current VR simulators available with haptic feedback are shown in Tables 3, 4, 5 [2, 6, 59].

\section{VR simulation with haptic feedback}

Currently, study results indicative for a true value of haptic feedback in VR simulation are low. Many conclusions on the subject are drawn from study results primarily based on the possible importance of haptic feedback in MIS, not so much in VR training [5, 25, 33, 60, 61].

The majority of studies support the idea that haptic feedback should be implemented onto VR simulators [5, 33, 62]. Various forms of haptic feedback can only be felt up to four or five different levels-important information for simulator calibration [5]. Some results suggest that the addition of haptic feedback in an early training phase may improve the trainee's performance, by enhancing the trainee's sensoric perception capabilities and thus facilitating transfer of skill from simulation to the operating room [31, $33,63]$. It is suggested that force feedback is a must for VR simulators if tissue consistency information is to be delivered [33]. This is supported by the study results of Chamarra et al. [64]. This group warns about a negative learning effect that may occur when performing tasks where pulling and pushing forces play a major role on surgical task outcome, after being trained using VR systems without realistic haptics. Their recommendation is to use VR trainers solely to overcome hand-eye coordination problems and continue training using a classic box trainer in which training set-ups allow for realistic pulling and pushing forces.

Results of studies on the frictional forces of various trocars used in endoscopic surgery further emphasize the importance of the realism of implemented force feedback. Implementation of realistic haptic devices applicable to VR simulators seems to be difficult. One-first needs to know what type of haptic feedback in combination with disturbing frictional forces is optimal, realistic, and applicable to VR simulation [26, 39]. 
Table 2 Current status of haptic feedback in RAS

\begin{tabular}{|c|c|c|c|c|}
\hline Subject & Study purpose & Conclusion & $\begin{array}{l}\text { Level of } \\
\text { evidence }^{\mathrm{a}}\end{array}$ & $\begin{array}{l}\text { Literature } \\
\text { reference }\end{array}$ \\
\hline \multicolumn{5}{|l|}{ Consequences } \\
\hline \multirow{4}{*}{$\begin{array}{l}\text { Influence on } \\
\text { operative times of } \\
\text { absence of haptic } \\
\text { feedback }\end{array}$} & $\begin{array}{l}\text { Compare robotically and traditionally } \\
\text { performed laparoscopic colorectal surgery }\end{array}$ & $\begin{array}{l}\text { Absence of haptic feedback prolongs operative } \\
\text { times in robot-assisted colorectal surgery }\end{array}$ & $1 b$ & [47] \\
\hline & $\begin{array}{l}\text { Trial of robot-assisted vs. laparoscopic Nissen } \\
\text { fundoplication }\end{array}$ & $\begin{array}{l}\text { Absence of haptic feedback prolongs operative } \\
\text { times in robot-assisted Nissen fundoplication }\end{array}$ & $1 b$ & {$[48]$} \\
\hline & $\begin{array}{l}\text { Study the feasibility of the Nissen procedure } \\
\text { using the da Vinci robot and evaluate the } \\
\text { benefits and costs new technique compared } \\
\text { with the conventional laparoscopic approach }\end{array}$ & $\begin{array}{l}\text { Absence of haptic feedback prolongs operative } \\
\text { times in robot-assisted cholecystectomy }\end{array}$ & $1 \mathrm{~b}$ & [49] \\
\hline & $\begin{array}{l}\text { Evaluate the efficiency and feasibility of } \\
\text { robotically assisted cholecystecomy } \\
\text { compared with standard laparoscopic } \\
\text { cholecystectomy. }\end{array}$ & $\begin{array}{l}\text { Absence of haptic feedback prolongs operative } \\
\text { times in robot-assisted coronary artery bypass } \\
\text { surgery }\end{array}$ & $1 \mathrm{~b}$ & {$[50]$} \\
\hline \multirow{3}{*}{$\begin{array}{l}\text { Influence on surgical } \\
\text { performance of } \\
\text { absence of haptic } \\
\text { feedback }\end{array}$} & $\begin{array}{l}\text { Does haptic feedback, in the form of sensory } \\
\text { substitution, facilitate the performance of } \\
\text { surgical knot tying? }\end{array}$ & $\begin{array}{l}\text { Haptic feedback increases consistency, } \\
\text { precision, and performance in robotic knot } \\
\text { tying }\end{array}$ & $3 b$ & [7] \\
\hline & & $\begin{array}{l}\text { Without haptic feedback, sutures and tissues are } \\
\text { torn, even by experienced surgeons }\end{array}$ & & \\
\hline & $\begin{array}{l}\text { Role of force feedback in blunt, surgical, } \\
\text { dissection }\end{array}$ & $\begin{array}{l}\text { Absence of force feedback increased the } \\
\text { number of errors that damage tissue by factor } \\
3\end{array}$ & $3 b$ & {$[51]$} \\
\hline \multicolumn{5}{|l|}{ Possible solutions } \\
\hline \multirow[t]{2}{*}{$\begin{array}{l}\text { Alternative forms of } \\
\text { feedback }\end{array}$} & $\begin{array}{l}\text { Does haptic feedback, in the form of sensory } \\
\text { substitution, facilitate the performance of } \\
\text { surgical knot tying? }\end{array}$ & $\begin{array}{l}\text { Visual sensory substitution helps to apply more } \\
\text { consistent, precise, and greater tensions to } \\
\text { fine suture materials without breakage during } \\
\text { RAS }\end{array}$ & $3 b$ & [7] [51] \\
\hline & $\begin{array}{l}\text { Overview of research in dexterous } \\
\text { manipulation }\end{array}$ & $\begin{array}{l}\text { Audio feedback is proven as a valuable sensory } \\
\text { substitution }\end{array}$ & 4 & {$[55]$} \\
\hline $\begin{array}{l}\text { Addition of haptic } \\
\text { feedback }\end{array}$ & $\begin{array}{l}\text { Test pneumatic haptic feedback actuator array, } \\
\text { suitable for mounting on surgical robotic } \\
\text { tools }\end{array}$ & $\begin{array}{l}\text { Pneumatic balloon-based actuation is a viable } \\
\text { solution for generating haptic feedback in } \\
\text { RAS }\end{array}$ & $3 b$ & $\begin{array}{l}{[55]} \\
{[56]}\end{array}$ \\
\hline
\end{tabular}

Studies were conducted as literary review, individual case-control study, prospective randomized trial, or randomized clinical trial

a Based on the guidelines of the Oxford Centre of Evidence-based Medicine Levels of Evidence [17]

Table 3 MIS training devices and presence haptic feedback

\begin{tabular}{ll}
\hline Training device & $\begin{array}{l}\text { Haptic } \\
\text { feedback? }\end{array}$ \\
\hline Box trainers & Yes \\
Animal models & Yes \\
VR training without haptic feedback & No \\
VR training with haptic feedback & Yes \\
Augmented reality training $(\mathrm{AR})^{*}$ & Yes \\
\hline
\end{tabular}

Occasionally, the value of adding haptic feedback in VR training is discussed as experienced surgeons have long performed both CES and RAS, without force feedback, without complications [25, 60].

\section{Specific RAS training with haptic feedback}

Specific RAS-training methods are still in its infancy, and few study results are known on the subject. A preliminary
Table 4 Application of haptic feedback in VR training

\begin{tabular}{ll}
\hline Medical training & Clinical practice \\
\hline $\begin{array}{l}\text { Procedural training (e.g., broncho-/colono-/ } \\
\text { gastroscopy, cricothyroidotomy, laparoscopic } \\
\text { cholecystectomy, vascular interventions) }\end{array}$ & $\begin{array}{c}\text { Surgery/treatment planning (e.g., testing of } \\
\text { multiple reconfigurations for reconstructive }\end{array}$ \\
Anatomy learning (e.g., palpation and dissection) & Robotic surgery \\
& $\begin{array}{l}\text { Diagnostics (e.g., medical image interpretation, } \\
\text { invasive procedures, tumor diagnostics) }\end{array}$ \\
\hline
\end{tabular}


Table 5 Currently available VR trainers with haptic feedback appliance

\begin{tabular}{ll}
\hline VR trainer & Manufacturer \\
\hline Procedicus MIST & Mentice (www.mentice.com) \\
Lapsim Basic Skills/Dissection/ & Surgical Science \\
$\quad$ Gyn & (www.surgical-science.com) \\
Reachin Laparoscopic Trainer & Reachin Technologies \\
& (www.reachin.se) \\
Virtual Endoscopic Surgery & Select IT VEST Systems \\
Trainer & (www.select-it.de) \\
\hline
\end{tabular}

study by Jacobs et al. demonstrated the potential value and impact of training RAS with a combination of haptic and visual feedback [65]. Results indicate improved training performances with applied haptic feedback as to task completion time, accuracy, and number of errors made compared with task performances with only visual feedback, suggesting a complete altering of RAS training in the future.
Recapitulating the results of forementioned studies, as with MIS, there is no absolute consensus on the importance of haptic feedback in (VR) training for MIS. To date, little is known on the subject. Preliminary studies indicate a positive result of the addition of haptic feedback to VR simulation for MIS and RAS training regarding training performance. It is believed that the degree of realism of implemented haptic feedback is to play a crucial role in task-specific VR training. In general, studies do not qualify above a level of evidence 3b [17]. A summary of the known study results concerning haptic feedback in VR training is displayed in Table 6 .

\section{Discussion}

Reflected in literature are many studies assessing the characteristics, possible benefits, and drawbacks of haptic

Table 6 Current status of haptic feedback in VR simulation and RAS training

\begin{tabular}{|c|c|c|c|c|}
\hline Subject & Study purpose & Conclusion & $\begin{array}{l}\text { Level of } \\
\text { evidence }^{\mathrm{a}}\end{array}$ & $\begin{array}{l}\text { Literature } \\
\text { reference }\end{array}$ \\
\hline \multirow[t]{8}{*}{ Miscellaneous } & $\begin{array}{l}\text { Evaluate the role of force feedback with } \\
\text { applications to minimally invasive surgery }\end{array}$ & $\begin{array}{l}\text { Haptic feedback is essential to deliver tissue } \\
\text { consistency } \\
\text { Various forms of haptic feedback can only be } \\
\text { felt up to } 4 \text { or } 5 \text { different levels }\end{array}$ & $3 b$ & {$[5]$} \\
\hline & $\begin{array}{l}\text { Does addition of haptics improve } \\
\text { performance in surgical training? }\end{array}$ & $\begin{array}{l}\text { Early exposure to haptic feedback enhances } \\
\text { performance in surgical simulator training } \\
\text { Sensory stimuli are more important than } \\
\text { visual cues. During early stages of training, } \\
\text { sensory perception capabilities improve }\end{array}$ & $3 b$ & [31] [33] \\
\hline & Study perception of tissue consistency & $\begin{array}{l}\text { VR simulators need haptic devices with force } \\
\text { feedback capability if tissue consistency } \\
\text { information is to be delivered }\end{array}$ & $3 b$ & [33] [64] \\
\hline & $\begin{array}{l}\text { Determine whether force feedback influences } \\
\text { movements of instruments }\end{array}$ & $\begin{array}{l}\text { Negative learning effect may occur when } \\
\text { performing tasks where pulling and } \\
\text { pushing forces play a role in VR systems } \\
\text { without haptics }\end{array}$ & & \\
\hline & $\begin{array}{l}\text { Characterize laparoscopic gestures and } \\
\text { quantitative measurement of the various } \\
\text { interactions between organs and } \\
\text { instrument }\end{array}$ & $\begin{array}{l}\text { The question of whether to equip a trainee's } \\
\text { simulator with a force feedback system } \\
\text { remains open }\end{array}$ & $3 b$ & [26] \\
\hline & $\begin{array}{l}\text { Description of a framework that includes } \\
\text { most of the important aspects of haptics in } \\
\text { minimally invasive surgical simulation and } \\
\text { training }\end{array}$ & $\begin{array}{l}\text { Haptic feedback involves touching, feeling, } \\
\text { and manipulating organs through } \\
\text { instruments and should be implemented in } \\
\text { MIS and VR training }\end{array}$ & $3 b$ & {$[61]$} \\
\hline & $\begin{array}{l}\text { Current status in acquisition and assessment } \\
\text { of surgical skills by using VR simulators }\end{array}$ & $\begin{array}{l}\text { Haptic feedback is the most important factor } \\
\text { in learning surgical dexterous skills }\end{array}$ & $3 b$ & {$[62]$} \\
\hline & $\begin{array}{l}\text { Demonstrate the potential value of haptic and } \\
\text { visual feedback combined in RAS training }\end{array}$ & $\begin{array}{l}\text { Compared with traditional use of only visual } \\
\text { feedback, a combination of haptic and } \\
\text { visual feedback improves training } \\
\text { accuracy, fastens task completion times, } \\
\text { and decreases number of errors }\end{array}$ & $3 b$ & {$[65]$} \\
\hline
\end{tabular}

Studies were conducted as literary review or individual case-control study

a Based on the guidelines of the Oxford Centre of Evidence-based Medicine Levels of Evidence [17] 
feedback in relation to the various forms of minimally invasive surgery, conventional endoscopic surgery, roboticassisted surgery, and MIS training. In an overview of the results, one could state that there is no clear and absolute consensus found on the benefits of haptic feedback in MIS and MIS training. However, scrutinizing the results in more detail, the authors feel that one's opinion is not likely to be firm.

Upon assessing the evidence, authors assessed both the interarticle consensus on the respective topics and the extent to which evidence seemed to be useful in answering the questions annotated in the introduction of this article.

The cause of haptic limitations in performing MIS is well assessed and caused by the interposition of endoscopic instruments. Despite this alteration in haptics, researchers agree that interpretation of texture, shape, and tissue consistency is possible in current CES, but not in current RAS. Studies assessing quantification of sensitivity loss report variation in received haptic feedback, depending on frictional forces and specific tasks being performed. Exact quantification of haptic alteration is not unanimous, but results so far are in concordance.

Then, what kind of haptic input-or how many different levels of force-does a CES surgeon actually receive? And what type of force generated through haptic feedback is optimal? Reports on generated forces during endoscopic gestures range from 0.1-12 Newton, translating into a surgical interpretation of only up to four or five different levels of haptic feedback in the operative situation. This is important information when attempting to apply haptics into VR surgical simulation and in calibrating simulators. The optimal, most realistic type of haptic feedback for possible implementation remains unclear to authors. Both the ideal type of generated force feedback as well as the ideal mechanical efficiency of endoscopic instruments depends on the specific task being performed.

To perform optimal MIS and VR training, one must first and foremost rely on the visual deformation of tissue when haptics are absent, even more so in RAS than in CES. This states the obvious, because haptics are completely lacking in current RAS. Further results, which indicate the huge value of three-dimensional vision restoration that occurs in RAS, also seem logical. Multiple studies report direct improvements in performance times and accuracy, and a decrease in error rate for both inexperienced and experienced endoscopic surgeons after three-dimensional restoration in MIS. Suitable substitutions for current loss of haptics have possibly been found in visual cues and auditory feedback. One might view these substitutions as a type of haptic feedback. Force sensors need to be implemented into instruments used to report exerted forces through visual color bars or some sort of auditory feedback when handling tissue.

In which areas of VR training and in which way can haptic feedback be applied? The fields of application could possibly be both medical training and clinical practice. Little is known about the optimal and most realistic type of haptic feedback to be implemented into VR simulators. The realism of the haptic feedback will have a decisive role in the possible success of implementation.

The key question for future research on the matter should be: are results in CES or RAS improved by adding haptic feedback? For now, besides reduced operative times, the small amount of results indicating a favorable effect of haptic feedback on surgical performance and patient safety are merely obtained by individual case-control studies (level of evidence, 3b-4) [17]. Furthermore, research populations - consisting of surgeons and residents-were, in general, small ( $<20$ study subjects) and not multicentered.

Whether possible improvement in MIS outcome by adding haptics is a stable trait remains unclear. Throughout literature, no results were found, pointing out indifferent influences of possible addition of force feedback on operative parameters, let alone negative effects. The few opposing remarks made on haptic feedback are primarily based on the thesis that experienced surgeons have long been able to perform MIS without force feedback without complication. This seems to be the main reason that results are heterogenous, and although a favorable opinion on the benefits of haptic feedback is common, interarticle concensus cannot be fully obtained.

\section{Conclusions and recommendations}

Although information on haptic feedback regarding MIS and especially MIS VR training is rare throughout the literature, study results are indicative toward a positive consensus on the benefits of adding haptic feedback to MIS (-trainers). Interarticle consensus is, however, neither absolute nor firm. Objective, clinical end parameters of significance have not yet been established. The general level of evidence found for study results is $3 \mathrm{~b}$, according to the guidelines of the Oxford Centre of Evidence-based Medicine Levels of Evidence. As in all fields of health care and medicine, due to technological innovations, the current rate of haptic device developments and clinical MIS applications is high, and studies are expected to emerge rapidly on the subject.

The majority of studies report benefits when adding force feedback to MIS devices and, moreover, indicate drawbacks when haptic feedback is absent. The degree of realism of implemented haptic feedback related to the particular task that is being trained will have a key role in the future. Benefits are least disputed in the area of robotic surgery, because haptic feedback is absent in robotic surgical devices. Nevertheless, the addition of haptics is believed to reduce surgical errors and potentially increase patient safety. 
Regarding various forms of MIS, randomized and controlled trials that assess instruments with and without force feedback need to be studied. Regarding VR trainers, randomized and controlled trials that add haptics to VR under similar conditions are needed to establish the true value of such costly equipment in MIS training.

More objective study results based on valid end parameters-useful for assessing clinical relevance-need to be obtained to truly state the value of haptic feedback. For now, the question of the true value of haptic feedback in MIS training devices remains unanswered.

Open Access This article is distributed under the terms of the Creative Commons Attribution Noncommercial License which permits any noncommercial use, distribution, and reproduction in any medium, provided the original author(s) and source are credited.

\section{References}

1. Robles de la Torre G (2006) The importance of the sense of touch in virtual and real environments. IEEE Multimedia

2. Fager PJ (2004) The use of haptics in medical application. Int J Med Robotics Comput Assisted Surg 1:36-42

3. Dunkin B, Adrales GL, Apelgren K, Mellinger JD (2007) Surgical simulation: a current review. Surg Endosc 21:357-366

4. Lanfranco AR, Castellanos AE, Desai JP, Meyers WC (2004) Robotic surgery: a current perspective. Ann Surg 239:14-21

5. Tholey G, Desai JP, Castellanos AE (2005) Force feedback plays a significant role in minimally invasive surgery: results and analysis. Ann Surg 241:102-109

6. Roberts KE, Bell RL, Duffy AJ (2006) Evolution of surgical skills training. World J Gastroenterol 12:3219-3224

7. Bethea BT, Okamura AM, Kitagawa M, Fitton TP, Cattaneo SM, Gott VL, Baumgartner WA, Yuh DD (2004) Application of haptic feedback to robotic surgery. J Laparoendosc Adv Surg Tech A 14:191-195

8. Moody L, Baber C, Arvanitis TN (2002) Objective surgical performance evaluation based on haptic feedback. Stud Health Technol Inform 85:304-310

9. Grantcharov TP, Kristiansen VB, Bendix J, Bardram L, Rosenberg J, Funch-Jensen P (2004) Randomized clinical trial of virtual reality simulation for laparoscopic skills training. Br J Surg 91: $146-150$

10. Aggarwal R, Grantcharov T, Moorthy K, Hance J, Darzi A (2006) A competency-based virtual reality training curriculum for the acquisition of laparoscopic psychomotor skill. Am J Surg 191:128-133

11. Halvorsen FH, Elle OJ, Dalinin VV, Mork BE, Sorhus V, Rotnes JS et al (2006) Virtual reality simulator training equals mechanical robotic training in improving robot-assisted basic suturing skills. Surg Endosc 20:1565-1569

12. Lathan CE, Tracey MR, Sebrechts MM, Clawson DM, Higgins GA (2002) Using virtual environments as training simulators: measuring transfer. In: Stanney KM (ed) Handbook of virtual environments: design, implementation and applications. Lawrence Erlbaum Associates, Mahwah, pp 414-434

13. Seymour NE, Gallagher AG, Roman SA, O'Brien MK, Bansal VK, Andersen DK, Satava RM (2002) Virtual reality training improves operating room performance: results of a randomized, double-blinded study. Ann Surg 236:458-464

14. Schijven MP, Jakimowicz JJ, Broeders IAMJ, Tseng LNL (2005) The Eindhoven laparoscopic cholecystectomy training course- improving operating room performance using virtual reality training. Surg Endosc 19:1220-1226

15. Aggarwal R, Tully A, Grantcharov T, Larsen CR, Miskry T, Farthing A, Darzi A (2007) Virtual reality simulation training can improve technical skills during laparoscopic salpingectomy for ectopic pregnancy. BJOG 114:656

16. Aggarwal R, Grantcharov TP, Eriksen JR, Blirup D, Kristiansen VB, Funch-Jensen P, Darzi A (2006) An evidence-based virtual reality training program for novice laparoscopic surgeons. Ann Surg 244:310-314

17. Philips B, Ball C, Sackett D, Badenoch D, Straus S, Haynes B, Dawes M (2001) Oxford Centre for Evidence-based Medicine Levels of Evidence

18. Keus F, De Jong JA, Gooszen HG, Van Laarhoven CJ (2006) Small-incision versus open cholecystectomy for patients with symptomatic cholecystolithiasis. Cochrane Database Syst Rev 4:CD004788

19. Keus F, De Jong JA, Gooszen HG, Van Laarhoven CJ (2006) Laparoscopic versus open cholecystectomy for patients with symptomatic cholecystolithiasis. Cochrane Database Syst Rev 4:CD006231

20. Barczynski M, Cichon S, Konturek A, Cichon W (2006) Minimally invasive video-assisted parathyroidectomy versus open minimally invasive parathyroidectomy for a solitary parathyroid adenoma: a prospective, randomized, blinded trial. World J Surg 30:721-731

21. Sekhar N, Torquati A, Youssef Y, Wright JK, Richards WO (2007) A comparison of 399 open and 568 laparoscopic gastric bypasses performed during a 4-year period. Surg Endosc 21:665-668

22. Kluivers KB, Hendriks JC, Mol BW, Bongers MY, Bremer GL, De Vet HC, Vierhout ME, Brolmann HA (2007) Quality of life and surgical outcome after total laparoscopic hysterectomy versus total abdominal hysterectomy for benign disease: a randomized, controlled trial. J Minim Invasive Gynecol 14:145-152

23. Staudacher C, Vignali A, Saverio DP, Elena O, Andrea T (2007) Laparoscopic vs. open total mesorectal excision in unselected patients with rectal cancer: impact on early outcome. Dis Colon Rectum 50:1324-1331

24. Tong DK, Law WL (2007) Laparoscopic versus open right hemicolectomy for carcinoma of the colon. JSLS 11:76-80

25. Heijnsdijk EAM, Pasdeloup A, van der Pijn AJ, Dankelman J, Gouma DJ (2004) The influence of force feedback and visual feedback in grasping tissue laparoscopically. Surg Endosc 18:980-985

26. Picod G, Jambon AC, Vinatier D, Dubois P (2005) What can the operator actually feel when performing a laparoscopy? Surg Endosc 19:95-100

27. Bridges M, Diamond DL (1999) The financial impact of teaching surgical residents in the operating room. Am J Surg 177:28-32

28. Fiedler MJ, Chen SJ, Judkins TN, Oleynikov D, Stergiou N (2007) Virtual reality for robotic laparoscopic surgical training. Stud Health Technol Inform 125:127-129

29. Albani JM, Lee DI (2007) Virtual reality-assisted robotic surgery simulation. J Endourol 21:285-287

30. Satava RM (1993) Virtual reality surgical simulator: the first steps. Surg Endosc 7:203-205

31. Ström P, Hedman L, Särna L, Kjellin A, Wredmark T, FelländerTsai L (2006) Early exposure to haptic feedback enhances performance in surgical simulator training: a prospective randomized crossover study in surgical residents. Surg Endosc 20:1383-1388

32. den Boer KT, Herder JL, Sjoerdsma W, Meijer DW, Gouma DJ, Stassen HG (1999) Sensitivity of laparoscopic dissectors: what can you feel? Surg Endosc 13:869-873

33. Lamata P, Gomez EJ, Sanchez-Margallo FM, Lamata F, del Pozo F, Uson J (2006) Tissue consistency perception in laparascopy to 
define the level of fidelity in virtual reality simulation. Surg Endosc 20:1368-1375

34. Lehnert M, Richter B, Beyer PA, Heller K (2006) A prospective study comparing operative time in conventional laparoscopic and robotically assisted Thal semifundoplication in children. J Pediatr Surg 41:1392-1396

35. Rosen J, Hannaford B, MacFarlane MP, Sinanan MN (1999) Force controlled and teleoperated endoscopic grasper for minimally invasive surgery-experimental performance evaluation. IEEE Trans Biomed Eng 46:1212-1221

36. Bholat OS, Haluck RS, Murray WB, Gorman PJ, Krummel TM (1999) Tactile feedback is present during minimally invasive surgery. J Am Coll Surg 198:349-355

37. Bholat OS, Halluck RS, Kutz RH, Gorman PJ, Krummel TM (1999) Defining the role of haptic feedback in minimally invasive surgery. Stud Health Technol Inform 62:62-66

38. Toledo L, Gossot D, Fritsch S, Revillon Y, Reboulet C (1999) Study of sustained forces and the working space of endoscopic surgery instruments. Ann Chir 53:587-597

39. van den Dobbelsteen JJ, Schooleman A, Dankelman J (2006) Friction dynamics of trocars. Surg Endosc 21:1338-1343

40. Van der Peijl AJ, Herder JL (2001) Development of 5-mm trocar laparoscopic forceps with mechanical force feedback. Proceedings of the Design Engineering Technical Conferences 2001, American Society of Mechanical Engineers, 3-12 September 2001, DETC 01, ASME Conference, Pittsburgh, PA, USA

41. Balázs M, Feussner H, Hirzinger G, Omote K, Ungeheuer A (1998) A new tool for minor-access surgery: replacing mechanical joints in laparoscopic forceps with elastic beams for improved pressure control and sensitivity. IEEE Eng Med Biol 17:45-48

42. Herder JL, Horward MJ, Sjoerdsma W (1997) A laparoscopic grasper with force perception. Minim Invasive Ther Allied Technol 6:279-286

43. Howe RD, Peine WJ, Kontarinis DA, Son JS (1995) Remote palpation technology. IEEE Eng Med Biol 14:318-323

44. Sjoerdsma W, Herder JL, Horward MJ, Jansen A, Bannenberg JJG, Grimbergen CA (1997) Force transmission of laparoscopic grasping instruments. Minim Invasive Ther Allied Technol 6:274-278

45. Heijnsdijk EAM, Dankelman J, Gouma DJ (2002) Effectiveness of grasping and duration of clamping using laparoscopic graspers. Surg Endosc 16:1329-1331

46. Westebring-van der Putten EP, Goossens RH, Jakimowicz JJ, Dankelman J (2008) Haptics in minimally invasive surgery-a review. Minim Invasive Ther Allied Technol 17:3-16

47. Delaney CP, Lynch AC, Senagore AJ, Fazio VW (2003) Comparison of robotically performed and traditional laparoscopic colorectal surger. Dis Colon Rectum 46:1633-1639

48. Morino M, Pellegrino L, Giaccone C, Garrone C, Rebecchi F (2006) Randomized clinical trial of robot-assisted versus laparoscopic Nissen fundoplication. Br J Surg 93:553-558

49. Nakadi IE, Melot C, Closset J, DeMoor V, Betroune K, Feron P, Lingier P, Gelin M (2006) Evaluation of da Vinci Nissen fundoplication clinical results and cost minimization. World J Surg 30:1050-1054
50. Kornprat $\mathrm{P}$, Werkgartner $\mathrm{G}$, Cerwenka H, Bacher H, El-Shabrawi A, Rehak P, Mischinger HJ (2006) Prospective study comparing standard and robotically assisted laparoscopic cholecystectomy. Langenbechks Arch Surg 391:216-221

51. Wagner CR, Soupoulos N, Howe RD (2002) The role of force feedback in surgery: analysis of blunt dissection. 10th Symposium on Haptic Interfaces for Virtual Environment and Teleoperator Systems (HAPTICS), 24-28 March 2002, pp 68-74

52. Badani KK, Bhandari K, Tewari A, Menon M (2005) Comparison of two-dimensional and three-dimensional suturing: is there a difference in a robotic surgery setting? J Endourol 19:1212-1215

53. Falk V, Mintz D, Grünenfelder J, Fann JI, Burdon TA (2001) Influence of three-dimensional vision on surgical telemanipulator performance. Surg Endosc 15:1282-1288

54. Byrn JC, Schluender S, Divino CM, Conrad J, Gurland B, Shlasko E, Szold A (2007) Three-dimensional imaging improves surgical performance for both novice and experienced operators using the da Vinci Robot System. Am J Surg 193:519-522

55. Okamura A, Smaby N, Cutkosky M (2000) An overview of dexterous manipulation. ICRA 1:255-262

56. King CH, Higa AT, Culjat MO, Han SH, Bisley JW, Carman GP, Dutson E, Grundfest WS (2007) A pneumatic haptic feedback actuator array for robotic surgery of simulation. Stud Health Technol Inform 125:217-222

57. Tavakoli M, Patel RV, Moallem M (2005) Haptic interaction in robot-assisted endoscopic surgery: a sensorized end-effector. Int J Med Robot 1:53-63

58. Ruurda JP, ThJMV Van Vroonhoven, Broeders IAMJ (2002) Robot-assisted surgical systems: a new era in laparoscopic surgery. Ann R Coll Surg Engl 84:223-226

59. Botden SM, Buzink SN, Schijven MP, Jakimowicz JJ (2007) Augmented versus virtual reality laparoscopic simulation: what is the difference? A comparison of the ProMIS Augmented Reality Laparoscopic Simulator versus LapSim Virtual Reality Laparoscopic Simulator. World J Surg 31:764-772

60. Wilson MS, Middlebrook A, Sutton C, Stone R, McCloy RF (1997) MIST VR: a virtual reality trainer for laparoscopic surgery assesses performance. Ann R Coll Surg Engl 79:403-440

61. Basdogan C, De S, Jung K, Muniyandi M, Hyun K, Srinivasan MA (2004) Haptics in minimally invasive surgical simulation and training. IEEE Comput Graph Appl 24:56-64

62. Cosman PH, Cregan PC, Martin CJ, Cartmill JA (2002) Virtual reality simulators: current status in acquisition and assessment of surgical skills. ANZ J Surg 72:30-34

63. Kim HK, Ratter DW, Srinivasan MA (2003) The Role of Simulation Fidelity in Laparoscopic Surgical Training, 6th International Medical Image Computing and Computer Assisted

64. Chamarra MK, Dankelman J, van den Dobbelsteen JJ, Jansen FW (2008) Force feedback and basic laparoscopic skills. Surg Endosc 22:2140-2148

65. Jacobs S, Holzhev D, Strauss G, Burgert O, Falk V (2007) The impact of haptic learning in telemanipulator-assisted surgery. Surg Laparosc Endosc Percutan Tech 17:402-406 